the computations or calculations which have been made, either by doctors or assistant poor-law commissioners on the subject ; and if the guardians of the poor will not consent to give reasonable remuneration to a medical man for his attendance on the poor, the public must not expect them to be fairly or honestly taken care of.

"I beg you will have the goodness to communicate the contents of this note to the gentlemen who favoured the vice-presidents and myself with their company at the college, and that you will believe me to be most truly yours,

$$
\text { "G. J. Guthrie, President." }
$$

\section{ELEGANT EXTRACTS.}

\section{(From an inelegant Handbill.)}

"MACCLESFIELD MEDICAL AID SOCHETY.

“J. Turner, Esq., Park Green, Surgeon to the Society."

"The inhabitants of Macclesfield and its vicinity are respectfully informed, that a society is being organised, which, for a small weekly subscription, proposes to ensure to its members the benefit of medical attendance and medicine, in case of sickness."

"Whereas, for the trifling sum of one halfpenny per week to the Macclesteld Medical Aid Society; medicine and attendance may be had."

"The committee trust that a society concentrating in itself such advantages, at so small a cost, will meet with the approbation and patronag'e of the public, as they are conscious, from the great success of similar societies in the neighbouring towns, that if this is duly appreciated, their feeble efforts will meet with the support which they think the object deserves."

"This society admits families of all ages, in sickness or in health, residing within two and a half miles of the Macclesfield Sunday School. Each member shall pay one penny for entrance. Any female member paying sixpence on or before the birth of any of her children, such children shall become full members from the date of their birth."

"All persons paying one month's subscription, in addition to the entrance fee, on or before the 1st day of January, 1842, shall be full members, and entitled to ALL THE BENEFITS OF THE SOCIETY."

\section{BOOKS RECEIVED.}

Catalogue of the Preparations illustrative of Normal, Abnormal, and Morbid Structure, Human and Comparative, constituting the Anatomical Museum of George Langstaff. London: Churchill, 1842. 8vo. Pp.518.

On the Treatment of Stone in the Bladder by Medical and Mechanical Means. By $\mathbf{R}$. Willis, M.D. London: Baillière, 1842.
An Inquiry into the Nature and Pathology of Granular Disease of the Kidney, and its Mode of Action in producing Albuminous Urine. By George Robinson. London : Churchill, 1842. 8vo. Pp. 79.

Hydropathy; or the Cold-water Cure, as practised by Vincent Priessnitz. By R. T. Claridge. London: Madden, 1842. 8vo. Pp. 318.

\section{TO CORRESPONDENTS.}

Amadov Compresses. - Would Mr. Wetherfield be kind enough to inform a "Country Reader" where amadou may be obtained in sufficient quantities for the purposes to which he applies it.

Mr. Prout.-The proper time for learning Latin is at home or at school. A knowledge of the language ought not to have to be acquired at the period of life when the study of medicine itself should be commencing or is in progress.

A General Practitioner, at Macclesfield, in transmitting to us the handbill, from which we have elsewhere made sufficient extracts for all useful purposes, adds, - " Hitherto we have kept self-supporting bubbles, and other such attempts to degrade the profession, at bay; and although the medical attendance on clubs is bad enough, and but of recent introduction in this town, yet with respect to this 'medical-aid' scheme there appears to be no limit. The young man styled Esquire Turner is a partner with one of the senior medical men in Macclesfield, who would thus appear to give a colouring to the scheme, and to create a new form of outrage upon the profession, since formerly only adventurers were culprits in this way. Much indignation is manifested that so old a member of the profession should suffer his junior to become a party to such a contemptible affair."

J. E. should make the application; let him lay his case fairly before the lecturers; he has gentlemen to deal with, and we doubt not that he will receive a satisfactory reply. The application is unusual.

Mr. Horne's communication is an advertisement. The plan he recommends is one of daily practice in all our hospitals.

Brauntoniensis should forward copies of his letter and the reply, without which an opinion on the proceeding cannot be given.

Dr. Prichard's Natural History of MaN.-A correspondent, under the signature of Medicus, makes the following complaint: - "Some weeks ago it was announced on the cover of The LANCET that a new work, on the Natural History of Man, by Dr. Prichard, would speedily be published, to be completed in ten monthly parts, price of each eighteenpence. From the high scientific character of Dr. Prichard, and from the general usefulness of such a work, not only interesting to the medical profession but to the public at large, I instantly ordered the 